\title{
Antiovipositional and Antifertility Effects of Plant Extracts against the Flour Beetles, Tribolium castaneum (Herbst) and $T$. confusum (J. du Val)
}

\author{
L. A. M. Khanam ${ }^{1}$, A. R. Khan ${ }^{2}$, I. Mahfuz ${ }^{2}$ and D. Talukder ${ }^{1}$ \\ ${ }^{\text {I} B C S I R}$ Laboratories, Rajshahi, Rajshahi -6206, \\ ${ }^{2}$ Departmint of Zoology, Rajshahi University, Rajshahi-6205, Bangladesh
}

\begin{abstract}
Effects of petroleum ether extracts of Trichosanthes palmata seed and Zingiber cassumunar rhizome on the fecundity and fertility of two stored grain insect pests, Tribolium castaneum and Tribolium confusum have been assessed. Laboratory studies indicated that all the doses of T. palmata seed extract reduced significantly the egg laying and hatching of both the insects in comparison with the control. The mean oviposition per female for 33 days in the untreated medium were $232.05 \pm 9.91$ for T. castaneum and $215.00 \pm$ 14.43 for T. confusum respectively. The mean egg laying per female at the lowest (1000ppm) and the highest $(16000 \mathrm{ppm})$ doses were $130.20 \pm 11.52$ and $52.95 \pm 13.00$ for $T$. castaneum; and $146.75 \pm 17.66$ and $52.35 \pm$ 7.68 for $T$. confusum respectively. The mean hatching percentage of untreated T. castaneum and T. confusum were $69.90 \pm 1.73$ and $65.90 \pm 2.98$ respectively whereas the lowest mean value was $46.10 \pm 1.73$ for $T$. castaneum and $41.55 \pm 2.35$ for $T$. confusum at the highest dose (16000 ppm). Z. cassumunar rhizome extract also showed the toxic effect to both the insect species. Here the mean egg laying of control T. castaneum and $T$. confusum were $216.80 \pm 12.14$ and $223.85 \pm 13.54$ respectively. The mean oviposition of treated female at 1000 and 16000 ppm were $111.90 \pm 4.38$ and $45.20 \pm 7.62$ for T. castaneum; and $126.55 \pm 7.44$ and $54.55 \pm 8.10$ for T. confusum. The egg hatch at the highest dose was 48.80 for T. castaneum and 50.80 for T. confusum while the control values were 71.63 and 73.42 respectively.
\end{abstract}

Key words: Trichosanthes palmata seed, Zingiber. cassumunar rhizome, Tribolium castaneum, T. confusum, fecundity, fertility.

\section{Introduction}

The flour beetle, Tribolium castaneum (Herbst) and Tribolium confusum du Val are widely distributed throughout the world and are largely disseminated as grains are transported by commerce (Cotton 1947, Sokoloff 1974). The adults of these beetles are long lived and produce eggs continuously over a long period (Dick 1937, Good 1933). Fecundity and fertility are two important factors of paramount importance offering a great bearing on the number of offspring of an insect produced.

Golebiowska (1969) reported that intensive oviposition was depended on intensive feeding rate of the beetle. A number of plant products have been reported to reduce the fecundity in stored-products pests (Jacob and Sheila 1993, Chaiyaboot 1988, Rahman 1992, Amin 2000). Saxena et al. (1976) found that the vapours of Acorus calamus reduced fecundity and caused regression in the terminal follicle of the vitellarium in treated females of T. castaneum, S. oryzae, C. chinensis, $R$. granarium and Anthrenus flavipes.

Plants with aroma and smell generally contain essential oils and other smaller terpenoid molecules. Plants with exotic colours are more likely to contain various types of flavones, flavonoids and other plant phenolics. Similarly bitter testing plants are known to have various types of alkaloids (Rhaman and Choudhary 2005).

Khanam et al. (1999) reported the ovicidal activity of Annona reticulata against $T$. castaneum and $T$. confusum. Malek (2001) also reported the ovicidal activity of Annona squamosa seed oil and two new compounds on T. castaneum. Accordingly to Howe (1962), the intrinsic rate of increase of a pest is chiefly determined by the oviposition during its early life. The present experiment was aimed at determining the effects of locally available $T$. palmata seed and $Z$. cassumunar rhizome extracts on the reproductive potential of $T$. castaneum and $T$. confusum which will help in reducing the insect pest population in grain storage.

\section{Materials and Methods}

Fresh seeds of $T$. palmata and rhizomes of $Z$. cassumunar were utilized for preparing the extracts. The seeds and rhizomes dried in a well ventilated room under shade and finally dried in an oven at $40^{\circ} \mathrm{C}$. Dried plant parts were then powdered in a grinding machine and extraction was carried out with petroleum ether in a Soxhlet apparatus. Extracted materials were dried in a rotary evaporator and finally trace amounts of the solvent were removed by evaporating on a water bath, and then collected in a reagent bottle. 
A large number of beetles (T. castaneum and T. confusum) were collected and put on a thin layer of wheat flour in a medium size beaker previously passed through a 60-mesh sieve and the eggs were collected on the following day incubated at $30^{\circ} \mathrm{C}$ for hatching. Five different doses of seed and rhizome extracts of $T$. palmata and Z. cassumunar viz. 1000, 2000, 4000, 8000 and $16000 \mathrm{ppm}$ were used. The required quantities of the extractives were dissolved in $5 \mathrm{ml}$ acetone and then added to wheat flour. A control sample was used with acetone only. The treated foods were dried by fanning, kept in an incubator at $30^{\circ} \mathrm{C}$ for 24 hours and then put in a blender for proper mixing. Neonate larvae ( $<24$ hours) were transferred to glass beakers $(500 \mathrm{ml})$ containing treated food. A batch of control larvae was also similarly maintained. Larvae were checked from time to time for pupation. Pupae were sexed following Halstead (1963). Sexed pupae from different treatments were put on separate petridishes for adult emergence. Pairs of beetles of opposite sexes were introduced in different glass vials $(3.5 \times 1.8 \mathrm{~cm}$.) containing different treated food media. For each treatment 20 pairs of adult were employed for opposition. Eggs laid by females were counted by sieving the contents of the vials at 3-day intervals for 33 days. Eggs were observed on separate petri dishes till hatching. Percentage values are transformed into angles according to Bliss (1937). The percent reproductive control (P.R.C.) was calculated following Rizvi et al. (1980). as:

P.R.C. $=\frac{\mathrm{V}_{1}-\mathrm{V}_{2}}{\mathrm{~V}_{1}} \times 100$

Where $\mathrm{V}_{1}=$ Eggs laid by control female, and

$\mathrm{V}_{2}=$ Eggs laid by treated female

The experiment was conducted in an incubator at $30 \pm 1.5 \mathrm{C}^{0}$.

\section{Results and Discussion}

The effect of T. palmata seed extract on the fecundity and fertility of T. castaneum and T. confusum are given in Table I and illustrated in Fig. 1. Analyses of variance showed a highly significant $(\mathrm{P}<0.001)$ reduction in the fecundity of the beetles. Values of PRC also show a gradual reduction in oviposition of the insects depends upon the doses of the extracts. Fertility of beetles were reduced significantly $(\mathrm{P}<0.001)$ in comparison with the untreated controls. Results on fecundity and fertility of the above mentioned species due to the effect of Z. cassumunar rhizome extracts are presented in Table II (Fig. 2). All the treatment significantly $(\mathrm{P}<0.001)$ reduced the egg lying of the beetles. Values of PRC shows a better protection in offspring production of the beetle. Fertility of the beetles were similarly affected by the treatment and reduced significantly $(\mathrm{P}<0.001)$ in comparison with the untreated controls.

Secondary compounds from plants include alkaloids, terpenoids, phenolics, flavonoids, chromens and other minor chemicals can affect insects in several ways. They may disrupt major metabolic pathways, act as attractants, deterrents, phagostimulants, antifeedants and modify oviposition. They may also affect the insects' central nervous system and lifecycle of the insect in other ways (Smith 1989, Bell et al. 1990). Seeds of $T$. palmata contain cucurbitane glycosides, cucurbitacins and protease (Mohamed 1974). Z. cassumunar rhizome contain volatile oil, phenylbutenoid monomers, phenylbutenoid dimers and sesquiterpene zerrumbone ( Poonsapaya et al. 1993, Masuda and Jitoe 1994, 1995, Jitoe et al. 1993, Kishore and Dwivedi 1992).

Increase mortality in a population is generally compensated by increasing its net reproduction and it is well established that the multiplication or out break is greatly influenced by the fecundity of the species. Fertility, on the other hand, constitutes one of the most important factors for the survival of an insect and fertility factors are normally studied to evaluate their frequency in nature to elucidate the evolutionary forces, that maintain the set limits and to describe at various levels, viz. morphological, cytological, physiological and biochemical or any other anomalies found (Trippa et al. 1980).

These findings receive support from the result of Amin (2000) who reported antiovipositional and antifertility effect of Azadirachta indica and Vitex negundo in T. castaneum. Similarly, Yadava (1985) reported that the oil at the concentration ranging from 40 to $50 \mathrm{mg} / 10 \mathrm{gm}$ of green gram completely inhibited oviposition and fertility in Callosobruchus species. Caffeine and castor oil also reduced fertility in T. castaneum (Akhtar and Mondal 1994). Chaiyaboot (1988) reported that the application of neem seed powder at the rate of 5\% by weight decreased the number of eggs laid by Rhyzopertha dominica. Similarly Xu et al. (1993) observed Anise oil completely inhibited reproduction in $R$. dominica and Tenebrio molitor when mixed with wheat or wheat flour at concentration of $1 \%$ by weight. Cassia oils also completely inhibited reproduction in Sitophilus zeamais, $R$. dominica and T. castaneum (Xu and Zhao 1994). Khanam et al. (2008) noted that the acetone extract of Sapium inducm seed and petroleum ether extracts of Thevetia neriifolia seed kernel and Jatropa gossypifolia seed significantly reduced the reproductive potential of $T$. castaneum and $T$. confusum.

A perusal of the data clearly shows that T. palmata and Z. cassumunar rhizome extracts contain antiovipositional and antifertility components that could be used for the managements of storage pests. However, much more concerted efforts are very much to be directed toward this time. 


\section{Acknowledgements}

The first author wishes to express grateful thanks to the authority of Bangladesh Council of Scientific and Industrial Research, Bangladesh for granting study leave and for the financial support under the Human Resource Development Programme. The authors wish to express sincere thanks to the Chairman, Department of Zoology, University of Rajshahi, for providing necessary laboratory facilities.

\section{References}

[1]. N. Akhtar and K.A.M.S.H. Mondal, Effect of caffeine and castor oil on fecundity and fertility of Tribolium castaneum Herbst (Coleoptera: Tenebrionidae). Pakistan J. Zool. 26(2), 1994, 179-181.

[2]. T. Amin, Synergistic action of some indigenous plant materials with insecticides against Tribolium castaneum Herbst. Ph. D. thesis, Rajshahi University, Bangladesh, 2000, pp. 255.

[3]. E.A. Bell, L.E. Fellows and S.J. Simmonds, Natural products from plants for the control of insect pests. In: Safer insecticide development and use (E. Hodgson and R. J. Kuhr, eds.,1990), pp. 123-134. Marcel Dekker. USA.

[4]. C.I. Bliss, The analysis of field experimental data expressed in percentage. USSR Plant Prot. Bull. 12, 1937, 67-77.

[5]. S. Chaiyaboot, Protectant effect of powdered black pepper, neem and sugar apple seeds on stored cereals against Rhyzopertha dominica (F.). Munoz Nueva Ecija (Philippines). 1988, pp. 81.

[6]. R.T Cotton, Insect pests of stored grain and grain products. Burger Publishing Company, Minnesota, U.S.A., 1947, pp. 306.

[7]. J. Dick, Oviposition in certain Coleoptera. Ann. appl. Biol., 24, 1937, 762-796.

[8]. Z. Golebiowska, The feeding and fecundity of Sitophilus granarius (L.), Sitophilus oryzae (L.) and Rhyzopertha dominica (F.) in wheat grain. J. stored Prod. Res. 5, 1969, 143-155.

[9]. N.E. Good, Biology of the flour beetles T. confusum Duv. T. ferruginaeum Fab. J. Agric. Res. 46, 1933, 327-334.

[10]. D.G.H. Halstead, External sex differences in stored products Coleoptera. Bull. Ent. Res. 54, 1963, 119-134.

[11]. R.W. Howe, The effect of temperature and humidity on the oviposition rate of Tribolium castaneum (Herbst) (Coleoptera: Tenebrionidae). Bull.ent.Res.4, 1962, 213-220.

[12]. S. Jacob and M.K. Sheila, A note on the protection of stored rice from the lesser grain borer, Rhyzopertha dominica Fab. by indigenous plant products. Indian J. Ent. 55(3), 1993, 337-339.

[13]. L. A. M. Khanam, A. R., Khan, M. Khalequzzaman and S. M. Rahman,. Effect of Sapium indicum, Thevetia neriifolia and Jatropha gossypifolia seed extract on the fecundity and fertility of Tribolium castaneum and Tribolium confusum. Bangladesh J. Sci. Ind. Res. 43(1), 2008, 55-66.

[14]. L.A.M. Khanam, B. Parveen, M.A.Malek and D. Talukder, Ovicidal activity of Annona reticulata against Tribolium confusum and T. castaneum. Bangladesh J. Sci. Ind. Res. 34(3-4), 1999, 324-326.

[15]. N. Kishore and R.S. Dwivedi, Zerumbone: A potential fungitoxic agent isolated from Zingiber cassumunar Roxb. Mycopathologia (Banaras) 120 (3), 1992, 155-159

[16]. M.A. Malek, Ovicidal activity of Annona squamosa seed oil and its two new compounds on the insect Tribolium castaneum. J. Asiat. Soc. Bangladesh, Sci. 27(2), 2001, 151-155.

[17]. A. Jitoe, T. Musuda and N. Nakatani, Phenylbutenoid dimmers from the rhizomes of Zingiber cassumunar. Phytochemistry 32,1993, 357-363.

[18]. T. Masuda, and A. Jitoe, Antioxidative anti-inflammatory compounds from tropical ginger: Isolation, Structure determination and activities of cassumunius A, B and C, New complex cucurminoids from Zingiber cassumunar. J. Agric. Fd. Chem.(USA), 42, 1994, $1850-1856$.

[19]. T. Masuda and A. Jitoe, Phenylbutenoid monomers from the rhizome of Zingiber cassumunar. Phytochemistry 39, 1995, 459-461

[20]. P.A. Mohamed, Isolation of Trichotetrol- New tetrahydroxy pentacyclic triterpene from Trichosanthes bracteata (Cucurbitaceae ) Linn- voight Syn. T. palmata (Rox). J. current Science 43 (4), 1974, 116.

[21]. P. Poonsapaya, K. Kraisinta, D. Paleviteh and E. Putievsky, Micropropagation of Zingiber cassumunar Roxb. Acta Horticulture 344, 1993, 557-564

[22]. A. Rahman and M.I. Choudhary, Logical approach to structure elucidation of natural compounds. Paper presented at the National Workshop on the Pesticidal Plants of Bangladesh. Manarat International University , Dhaka, 2005, 29-30 September.

[23]. A.S.M.S. Rahman, Combined action of pirimiphos-methyl, synthetic methylquinone and botanicals on Tribolium confusum Duval. Ph.D. thesis, University of Rajshahi, Bangladesh, 1992, 232 pp.

[24]. S.J.A. Rizvi, S.K. Pandey, D. Muderjii and S.K. Mathur, 1,3,7- Trimethylxanthine, a new chemosterilant for stored grain pest, Collosobruchus chinensis L. Z. angew. Ent. 90, 1980, 378-381.

[25]. B.P. Saxena, O. Koul and K. Tikku, Non-toxic protectants against the stored grain insect pests. Bull. Grain Tech. 14, 1976, 190193.

[26]. C. M. Smith, Plant resistance to insects. A fundamental approach, John Wiley Sons, Inc., 1989, pp. 286.

[27]. A. Sokoloff, The biology of Tribolium with special emphasis on genetic aspects. Vol. 2. Clarendon Press, Oxford., 1974, pp. 610.

[28]. G. Trippa, A. Loverre and R. Ciccheti, Male fertility in female sterile mutant of Drosophila melanogaster. J. exp. Zool. 214, 1980, 277-285.

[29]. H. Xu and S.H. Zhao, Studies on insecticidal activity of Cassia oil and its toxic constituent analysis. J. South China Agric. Univ. 15(1), 1994, 27-33.

[30]. H.H. Xu, S.F. Chiu, F.Y. Jiang and G.W. Huang, Experiments on the use of essential oils against stored product insects in a storehouse. J. South China Agric. Univ. 14(3), 1993, $42-47$.

[31]. Yadava, T.D. Antiovipositional and ovicidal toxicity of neem (Azadirachta indica A. Juss) oil against the spp. of Callosobruchus. Neem newsletter 2, 1985, 5-6. 
Table I. Effect of petroleum ether extract of T. palmata seed on the fecundity and fertility of $T$. castaneum and $T$. confusum.

\begin{tabular}{|c|c|c|c|c|c|c|}
\hline Dose (ppm) & $\begin{array}{l}\text { No. of } \\
\text { females }\end{array}$ & $\begin{array}{l}\text { Fecundity } \\
\text { Mean } \pm \text { SE }\end{array}$ & $\begin{array}{c}\text { Mean daily eggs } \\
\text { lay per } \\
\text { female }\end{array}$ & $\begin{array}{l}\text { Percent } \\
\text { reproductive } \\
\text { control } \\
\text { P.R.C. }\end{array}$ & $\begin{array}{l}\text { (No. of eggs) } \\
\text { Fertility } \% \\
\text { Mean } \pm \text { SE }\end{array}$ & $\mathrm{d}$ - values \\
\hline Control & 20 & $\begin{array}{l}\text { a) } 232.05 \pm 9.90 \\
\text { b) } 215 \pm 14.43\end{array}$ & $\begin{array}{l}\text { a) } 7.00 \\
\text { b) } 6.53\end{array}$ & & 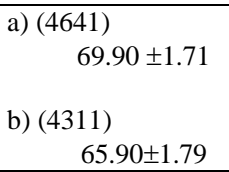 & - \\
\hline 1000 & 20 & $\begin{array}{l}\text { a) } 130.20 \pm 11.52 \\
\text { b) } 146.75 \pm 17.66\end{array}$ & $\begin{array}{l}\text { a) } 3.95 \\
\text { b) } 4.45\end{array}$ & $\begin{array}{l}\text { a) } 43.57 \\
\text { b) } 31.85\end{array}$ & $\begin{array}{l}\text { a) }(2604) \\
60.05 \pm 1.40 \\
\text { b) }(2935) \\
62.5 \pm 1.88\end{array}$ & $\begin{array}{l}\text { a) } 2.54^{\text {N.S. }} \\
\text { b) } 0.852^{\text {N.S. }}\end{array}$ \\
\hline 2000 & 20 & $\begin{array}{l}\text { a) } 98.75 \pm 4.23 \\
\text { b) } 135.15 \pm 18.99\end{array}$ & $\begin{array}{l}\text { a) } 2.99 \\
\text { b) } 4.10\end{array}$ & $\begin{array}{l}\text { a) } 57.29 \\
\text { b) } 37.21\end{array}$ & $\begin{array}{l}\text { a) }(1975) \\
58.99 \pm 1.82 \\
\text { b) }(2703) \\
58.08 \pm 0.856\end{array}$ & $\begin{array}{l}\text { a) } 2.72^{* * *} \\
\text { b) } 1.96^{\text {N.S. }}\end{array}$ \\
\hline 4000 & 20 & $\begin{array}{l}\text { a) } 83.50 \pm 10.89 \\
\text { b) } 117.05 \pm 12.24\end{array}$ & $\begin{array}{l}\text { a) } 2.53 \\
\text { b) } 3.55\end{array}$ & $\begin{array}{l}\text { a) } 63.86 \\
\text { b) } 45.64\end{array}$ & 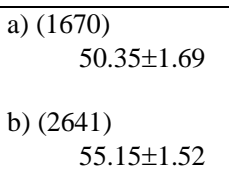 & $\begin{array}{l}\text { a) } 4.83^{* *} \\
\text { b) } 2.66^{* *}\end{array}$ \\
\hline 8000 & 20 & $\begin{array}{l}\text { a) } 59.95 \pm 10.49 \\
\text { b) } 117.05 \pm 11.54\end{array}$ & $\begin{array}{l}\text { a) } 1.82 \\
\text { b) } 2.12\end{array}$ & $\begin{array}{l}\text { a) } 74.00 \\
\text { b) } 67.53\end{array}$ & $\begin{array}{l}\text { a) } \begin{array}{l}(1199) \\
47.40 \pm 1.63\end{array} \\
\text { b) } \begin{array}{r}(1400) \\
51.82 \pm 1.37\end{array}\end{array}$ & $\begin{array}{l}\text { a) } 5.51^{* * *} \\
\text { b) } 3.46^{* *}\end{array}$ \\
\hline 16000 & 20 & $\begin{array}{l}\text { a) } 52.95 \pm 13.00 \\
\text { b) } 52.35 \pm 7.68\end{array}$ & $\begin{array}{l}\text { a) } 1.60 \\
\text { b) } 1.59\end{array}$ & $\begin{array}{l}\text { a) } 77.14 \\
\text { b) } 75.65\end{array}$ & $\begin{array}{l}\text { a) }(1059) \\
46.10 \pm 0.994 \\
\text { b) }(1047) \\
\quad 41.55 \pm 1.31\end{array}$ & $\begin{array}{l}\text { a) } 5.84^{* *} \\
\text { b) } 6.01^{* *}\end{array}$ \\
\hline
\end{tabular}

** Significant at $1 \% ;{ }^{\text {NS }}$ Not significant.

$\mathrm{d}=$ Standardized normal deviates.

$\mathrm{a}=T$. castaneum

$\mathrm{b}=T$. confusum

Table II. Effect of petroleum ether extract of Z. cassumunar rhizome on the fecundity and fertility of $T$. castaneum and $T$. confusum

\begin{tabular}{|c|c|c|c|c|c|c|}
\hline Dose (ppm) & No. of females & $\begin{array}{l}\text { Fecundity } \\
\text { Mean } \pm \text { SE }\end{array}$ & $\begin{array}{c}\text { Mean daily eggs } \\
\text { lay per } \\
\text { female }\end{array}$ & $\begin{array}{l}\text { Percent } \\
\text { reproductive } \\
\text { control } \\
\text { P.R.C. }\end{array}$ & $\begin{array}{c}\text { (No. of eggs }\} \text { Fertility } \\
\% \text { Mean } \pm \text { SE }\end{array}$ & $\mathrm{d}$ - values \\
\hline Control & 20 & $\begin{array}{l}\text { a) } 216.80 \pm 12.14 \\
\text { b) } 223.85 \pm 13.54\end{array}$ & $\begin{array}{l}\text { a) } 6.57 \\
\text { b) } 6.78\end{array}$ & & 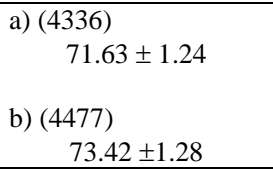 & $\begin{array}{l}- \\
-\end{array}$ \\
\hline 1000 & 20 & $\begin{array}{l}\text { a) } 111.90 \pm 4.38 \\
\text { b) }(126.55 \pm 7.44)\end{array}$ & $\begin{array}{l}\text { a) } 3.39 \\
\text { b) } 3.83\end{array}$ & $\begin{array}{l}\text { a) } 48.40 \\
\text { b) } 43.51\end{array}$ & $\begin{array}{l}\text { a) }(2238) \\
63.75 \pm 2.14 \\
\text { b) }(2531) \\
60.82 \pm 1.02\end{array}$ & $\begin{array}{l}\text { a) } 2.07^{*} \\
\text { b) } 3.32^{* *}\end{array}$ \\
\hline 2000 & 20 & $\begin{array}{l}\text { a) }(91.90 \pm 6.00) \\
\text { b) }(122.25 \pm 7.10)\end{array}$ & $\begin{array}{l}\text { a) } 2.78 \\
\text { b) } 3.70\end{array}$ & $\begin{array}{l}\text { a) } 57.69 \\
\text { b) } 45.43\end{array}$ & $\begin{array}{l}\text { a) }(1838) \\
59.98 \pm 1.88 \\
\text { b) }(2445) \\
58.24 \pm 0.915\end{array}$ & $\begin{array}{l}\text { a) } 2.94^{* *} \\
\text { b) } 3.79^{* *}\end{array}$ \\
\hline 4000 & 20 & $\begin{array}{l}\text { a) }(60.40 \pm 5.34) \\
\text { b) }(106.75 \pm 9.68)\end{array}$ & $\begin{array}{l}\text { a) } 1.83 \\
\text { b) } 3.23\end{array}$ & $\begin{array}{l}\text { a) } 72.15 \\
\text { b) } 52.36\end{array}$ & 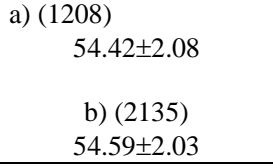 & $\begin{array}{l}\text { a) } 4.27^{* *} \\
\text { b) } 4.65^{* *}\end{array}$ \\
\hline
\end{tabular}


Antiovipositional and Antifertility Effects of Plant Extracts against the Flour Beetles, Tribolium

\begin{tabular}{|c|c|l|c|c|c|c|}
\hline 8000 & 20 & a) $(47.75 \pm 6.26)$ & a) 1.45 & a) 77.93 & $\begin{array}{c}\text { a) }(955) \\
49.77 \pm 2.11\end{array}$ & a) $5.37^{* *}$ \\
& b) $(57.35 \pm 7.14)$ & b) 1.74 & b) 74.93 & b) $(1147)$ \\
$53.14 \pm 2.49$ & b) $4.98^{* *}$ \\
\hline 16000 & 20 & a) $(45.20 \pm 7.62)$ & a) 1.37 & a) 79.15 & $\begin{array}{c}\text { a) }(904) \\
48.80 \pm 3.11\end{array}$ & a) $5.60^{* *}$ \\
& b) $(54.45 \pm 8.10)$ & b) 1.65 & b) 75.66 & b) (1089) & b) $5.55^{* *}$ \\
\hline
\end{tabular}

*, ** Significant at $5 \%$ and $1 \%$ respectively; ${ }^{\text {NS }}$ Not significant.

$\mathrm{d}=$ Standardized normal deviates.

$\mathrm{a}=T$. castaneum

$\mathrm{b}=T$. confusum
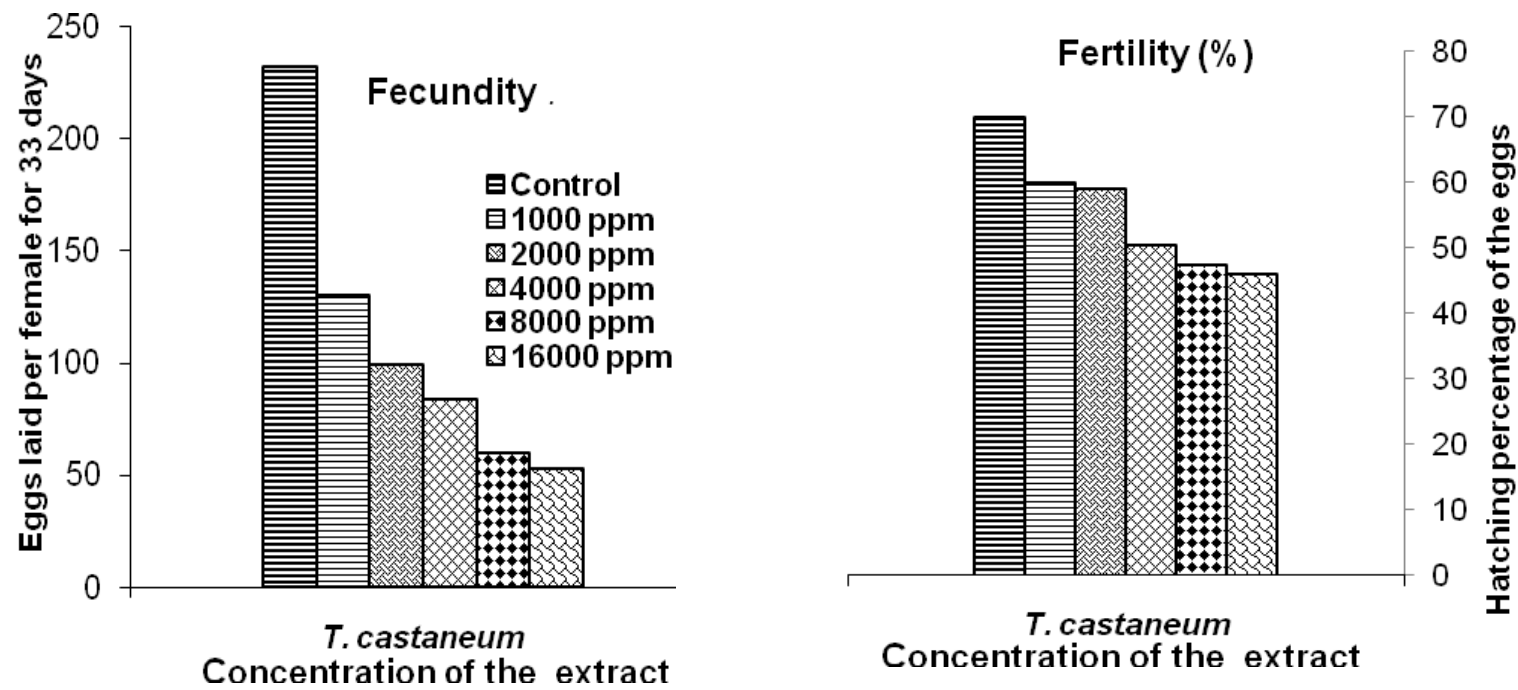

Concentration of the extract
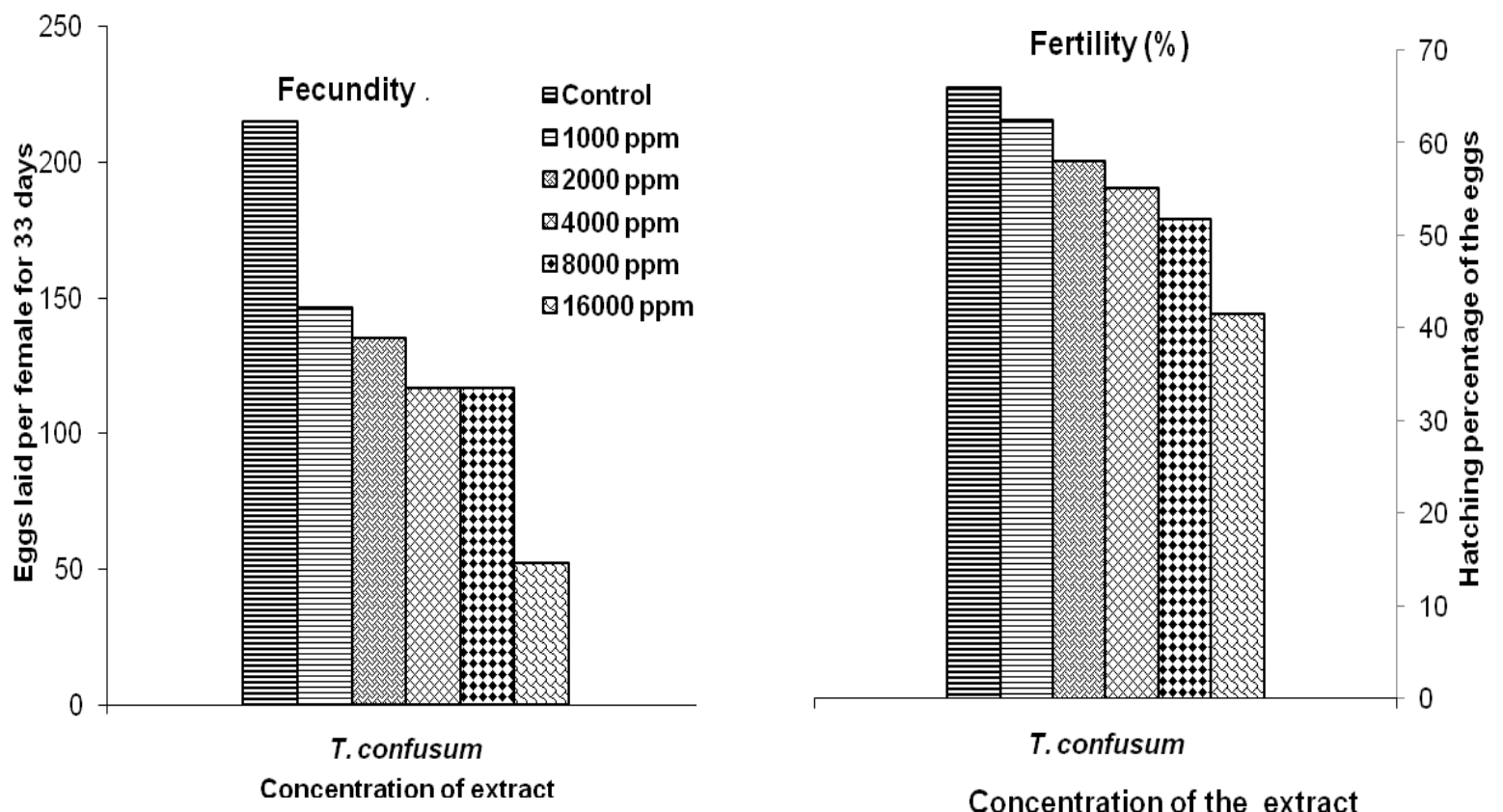

Fig-1. Showing the Effect of different doses of $T$. palmata seed extract on the fecundity and fertility of $T$. castaneum and $T$. confusum. 

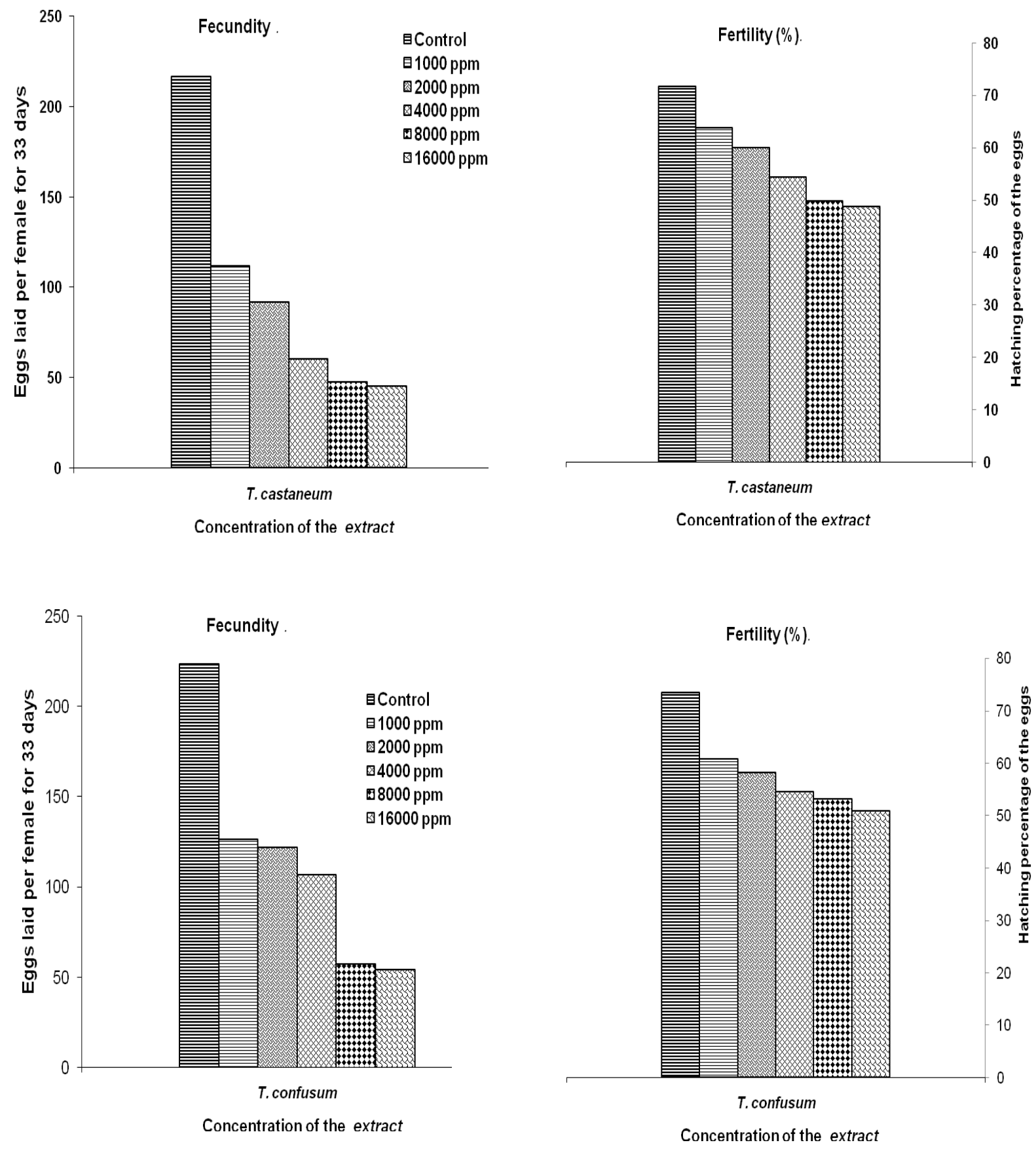

Fig-2. Showing the effect of different doses of $Z$. cassumunar rhizome extract on the fecundity and fertility of $T$. castaneum and $T$. confusum. 